\title{
A Mystical Reading of Hāfiz’’s Translation by Robert Bly and Leonard Lewisohn
}

\author{
Seyed Mohammad Anoosheh \\ Department of English Literature, Faculty of Humanities, Yazd University, Iran \\ Mahsa Khalili Jahromi \\ Department of English Literature, Faculty of Humanities, Yazd University, Iran
}

\begin{abstract}
Robert Bly and Leonard Lewisohn are among the latest translators of Ḥāfiz who have selectively translated thirty ghazals of Hāfiz into English. A close investigation of their translation reveals how they have manipulated the original texts to a great extent which results in having merely a mystical interpretation of Ḥāfiz̧'s multi-layered poems. However, due to the literary form of Ḥāfiz’s poetry which is ghazal, it can be in praise of different issues such as nature, youth, beloved, loveliness, etc.; in Bly and Lewisohn's translation, most of them have been ascribed to divinity. In other words, by means of translation, they have rendered their own worldview along with their personal reading of Hāfiz's poetry. The authors argue that Bly and Lewisohn's translation renders a mystical reading of Haafiz’'s poetry and presents him as a moral preacher whose poetry is saturated with mysticism and Sufism. Being highly against the American society's materialism, by introducing Ḥâfiz as a mystic and insisting on mystical and spiritual interpretation of his poetry they intend to survive their society from corruption and cater to the moral and spiritual needs of the target culture. Since American literature compared to Persian literature, lacks some repertoire related to mysticism thus Lewisohn and Bly, by means of translation try to provide their culture with a sort of nourishment in order to contribute to the amendment of the society.
\end{abstract}

Index Terms-Ḥāfiz, mysticism, sufism, translation studies, Robert Bly, Leonard Lewisohn

\section{INTRODUCTION}

Since the 1980s, translation has become central to comparative literature. Traditionally speaking, translation studies used to be a field concerning problems of linguistic and textual fidelity to the original. During the $20^{\text {th }}$ century, it developed and emerged as a new academic and interdisciplinary field (Apter, 2011, p. 3). Recently, translation studies has veered toward cultural studies and investigates how cultural issues might influence cultural interactions. Thus, in recent years, as comparative literature has declined in significance, translation studies has been gaining ground and it has become a discipline in its own right (Bassnett, 1998, p. 138). The original text through the process of translation undergoes several changes which are mostly due to cultural and linguistic differences as well as the translator's worldview. The translator first acts as a reader who has his/her own interpretation of the original text and inevitably his/her own mindset affects the process of translation. Consequently, the reader of the translated text gets to know the literary work and the author through the translator's point of view.

Among the translators who have translated Hāfiz’s poetry into English, Leonard Lewisohn and Robert Bly are among the latest ones. The esteemed American poet and author Robert Bly who worked with the great Islamic scholar Leonard Lewisohn, produced a translation named The Angels Knocking on the Tavern Door which encompasses the translation of thirty poems of Hāfiz. Since Hāfiz's poetry is multi-layered, there are a variety of different interpretations for it and every single verse can be interpreted differently but Bly and Lewisohn's have translated Hāfiz in a way that has confined its extensive and diverse interpretations to mysticism. In this paper, the authors attempt to have a close reading of the thirty translated poems and locate the verses emitting the mystical attitude of the translators toward Hāfiz and his poetry. It has been demonstrated how the verses have been manipulated in the process of translation in order to make them suit the translators' worldview and desire. The authors argue that Bly and Lewisohn's translation renders a mystical reading of Haafiz’s poetry and presents him as a moral preacher whose poetry is saturated with mysticism and Sufism. In fact, by introducing Ḥāfiz as a mystic and insisting on mystical and spiritual interpretation of his poetry they intend to cater to the moral and spiritual needs of the target culture and contribute to the amendment of the society.

\section{DISCUSSION}

\section{A. God, the Forever Beloved}

There are some assumptions about Hafez's beloveds. Eslami Nadooshan believes that there are three kinds of love or better to say beloveds in ghazals of Hafez: the first one can be one of his contemporaries, the second one is quite faceless and it can be a man, woman, a live person or even a dead one. The third one is the mystical love. (Khoramshahi, 1994, p. 195). In other words, Hāafiz’s poetry is open to different interpretations and it permits the reader to interpret it 
due to his/her own will. Thus, there is no absolute interpretation and no one can confidently assert who is the real addressee of his poem. The beloved has been addressed with different words and expressions in Hāfiz's poetry. The beloved can be either God or an earthly beloved (a man or a woman). But in the translation by Lewisohn and Bly, they have interpreted them all as God. Having a mystical viewpoint toward Hāfiz’s poetry, the translators have interpreted any talk of love as attributed to God, namely for them, all the love mentioned in the poems is toward God and it has been translated as divine and sacred; even in describing love they assign it a holy court (harime eshgh) (Hāfiz et al., 2009 , p. 55) that is in line with their spiritual interpretation of the poems. In some cases, instead of replacing the word alluding to the beloved with the word "God", they have applied capitalization to attribute it to God and attach divine status to it. For example:

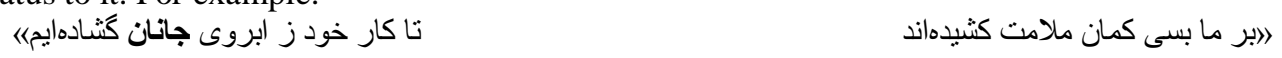

(Hāfiz, 1983, p. 728)

"People have aimed the arrow of guilt a hundred times

In our direction. With the help of our Darling's eyebrow,

Blame has been a blessing, and has opened all our work." (Hāfiz et al., 2009, p. 3)

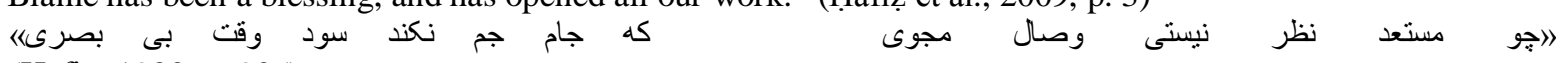

(Hāfiz, 1983, p. 905)

"Because you aren't worthy of the side glance

Of the Darling, don't try for union. Looking directly

Into Jamshid's cup doesn't work for the blind." (Hāfiz et al., 2009, p. 53)

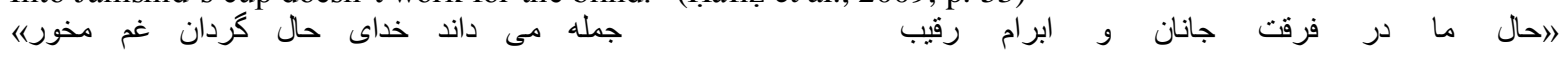

(Hāfiz, 1983, p. 516)

"God knows our whole spiritual state: separated

From Him and punished by rivals. Still do not

Sink into sadness. God is the one who changes conditions." (Hāfiz et al., 2009, p. 14)

Janãn (sweetheart; جانان) is a widely used word for referring to the beloved in Persian literature. It can be interpreted differently; some might consider it as an earthly beloved while for others, it might refer to God or any divine love. Since for Bly and Lewisohn, the beloved is always divine this word is translated as "Darling" (with capitalized D) and somewhere else, the same word is replaced by the pronoun "Him" (capitalized H). In fact, the translators in order to ascribe the love to God instead of translating the word janãn have replaced it with a pronoun to limit the interpretation of the verse and reinforces the argument that for the translators the beloved is always divine.

The following verse is another example that shows the translators' intend to prevent any probable interpretation which might be far from their own.

$$
\text { هر جند كه دورم از تو كه دور از تو كس مباد ليكن اميد وصل توام عن قريب است }
$$

(Hāfiz, 1983, p. 144)

"I may be a long way from you. Oh, God,

I don't want anyone to be distant! But I know

There is possibility for a close union with you." (Hāfiz et al., 2009, p. 11)

While in the above-mentioned verse, the poet by using a pronoun (تو: you) addresses his beloved, in translation, the word "God" is mentioned instead of the pronoun as if the poet is addressing God and he is the single addressee. On the contrary, the original verse is open to further interpretations; the addressee can be anyone else instead of God. Because in the original verse there is no specific hint that limits the addressee to God; it is possible that Hāfiz is addressing his earthly beloved not necessarily God.

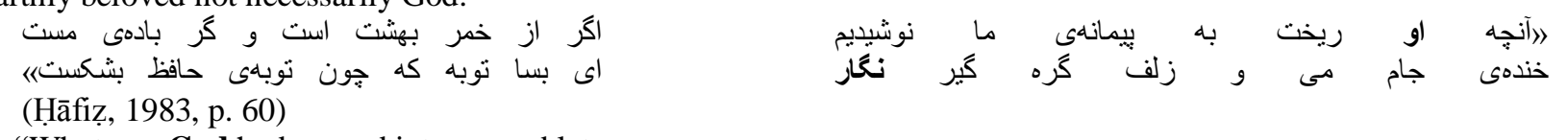

"Whatever God had poured into our goblet

We drank, whether it was the wine

Of heaven or the wine of drunkenness.

The laughter of the wine, and the disheveled curls

Of the One We Love ... How many nights of repentance-like

Hafez's - have been broken by moments like this?" (Hāfiz et al., 2009, p. 8)

There is no explicit reference to God in the original verses. It is mentioned as a pronoun, however the translators have replaced it with a noun "God" while there can be other possible interpretations for the pronoun (he/she:واو). At least it could be translated as "she" or "he" to save the ambiguity of the original text. On the other hand, in the second verse, the word نغار(negar; sweetheart) is mentioned which is a prevalent metaphor in Persian literature for the beautiful beloved; the translators in order to shift the focus from an earthly beloved to a divine one, have translated the word negar (ن) as "the One We Love" ; it is in line with the replacement of the pronoun (او) with "God" in the previous verse. In other words, the translators by using the pronoun "we" are putting emphasis on a thing that belongs to everyone and it is desirable for them all. Therefore, the whole sense of the verse is changed as if it is about the 
collective love that can be interpreted as God not an earthly beloved. The following verse is another example for the spiritual interpretation of love by the translators:

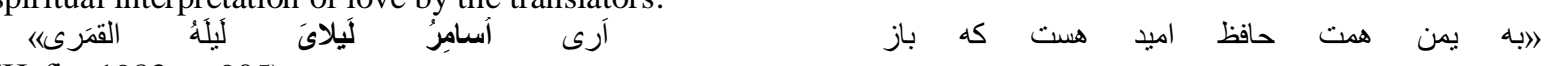

(Hāfiz, 1983, p. 905)

"Because of the good offices of Hafez, we can

Still hope that on some moonlit night we'll

Be able to enjoy our love conversation once more." (Hāifiz et al., 2009, p. 54)

The second part of the original verse is Arabic meaning that (there is hope that) I can see again the traces of my beloved (Laila) in the night's path. The word ليلا(Laila) is used for the beloved who is a desirable woman. In other words, the verse is about hoping to visit the beloved once again. But in the translation there is no talk of the beloved not to mention the earthly beloved. It is translated as a collective longing to enjoy the "love conversation" once more and it is not assigned who the addressee of the "love conversation" will be. Although there is a first person verb in the original verse, it has been modified to "we" and "our" in the translation in order to describe this love and the enjoyment of the company of the beloved as public not personal.

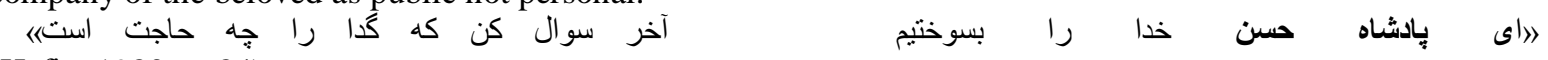

(Hāfiz, 1983, p. 84)

"Oh, Lord of Divine Loveliness, we have been

Burned to a crisp. Come now, ask of us

What is it a destitute and beggarly person needs?" (Hāfiz et al., 2009, p. 37)

However due to the literary form of Hāfiz's poetry which is ghazal, it can be in praise of many different issues such as nature, youth, beloved, loveliness, etc. (Shamîsa, 2007, p. 16); in Bly and Lewisohn's translation most of them have been ascribed to divinity because as discussed earlier, they consider Hāfiz as a mystical poet whose poetry is in praise of nothing but divinity. Thus, they have attributed not only the love to God but also any praise of loveliness has been given a divine aspect. For example, the above-mentioned verse praises the beauty and loveliness of the addressee but in translation the addressee is specified as God and the loveliness is described with the adjective, divine.

\section{B. The Omission of Pedophilia}

In pre-modern and early modern society of Iran an adolescent who is in his early twenties with the first trace of a mustache and before the full growth of beard and mustache was recognized as the utmost beauty. The first traces of a mustache (khat) signaled the beginning of his adult manhood and the movement from being an "object of desire" to a "desiring subject." In fact, love and desire were associated with beauty and they could be brought about by either a beautiful male or female. In other words, gender is irrelevant to love and beauty; while the same adjectives were used to describe both male and female bodies, even male beauty and male eroticism used to be recognized as the superior sentiments. In Persian literature, ghazal is the most celebrated genre for the expression of male homoeroticism (Najmabadi, 2010, pp.15-17). The issue of pedophilia is one of the cultural concepts that is prevalent in Hafez's poems. Undoubtedly the beloved of Hāfiz's poetry is male. In fact, homoeroticism was a prevalent custom at the time, it was even seen in monasteries and convents (Shamîsa, 2002, p. 167). The translation of this issue requires being highly familiar with the Persian language, literature and the culture of that time. The issue of pedophilia is omitted as much as possible in Bly and Lewisohn's translation of Haafiz. In other words, the translators intended to render a mystical interpretation of Hāfiz and introduce him as a mystic whose poetry is intertwined with merely mystical and spiritual issues. In fact, they have done their best to fudge and bowdlerize every single sign of praising and longing for the earthly beloved. But in some cases that there are conspicuous references to an earthly beloved that cannot be neglected; they preferred to attribute it to a beautiful woman instead of a young boy. The below-mentioned verses are the first three verses of the $22^{\text {th }}$ ghazal according to Khanlari's edition. In these verses, the beloved's posture is described while he/she is marching to the poet's bedside.

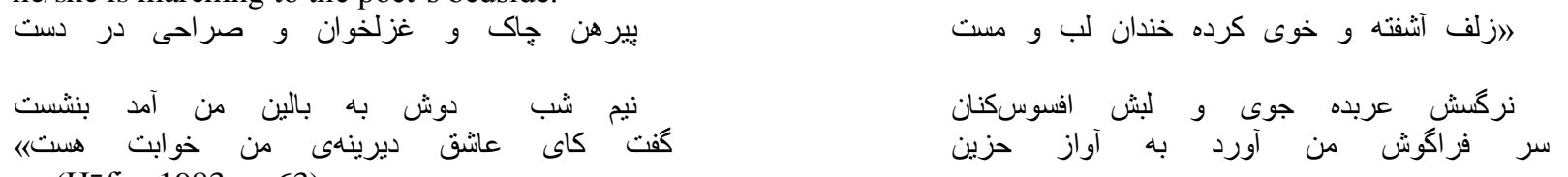

(Hāfiz, 1983, p. 63)

"Her hair was still tangled, her mouth still drunk

And laughing, her shoulders sweaty, the blouse

Torn open, singing love songs, her hand holding a wine cup.

Her eyes were looking for a drunken brawl,

Her mouth full of jibes. She sat down

Last night at midnight on my bed.

She put her lips close to my ear and said

In a mournful whisper these words: "What is this?

Aren't you my old lover? Are you asleep?"” (Hāfiz et al., 2009, p. 7)

Although Lewisohn and Bly by using possessive and personal pronouns (her and she) have underscored the femaleness of the beloved, some previous translators like Clarke have described the beloved as a young boy: "Tress 
although in most of the editions such as Ghazvini, Neysari, Eyvazi, and Saye "hasti” (existence) is used (Hamidiyan, 2010, p. 3854).

Javid (1996) believing hasti هنتى (existence) is the better choice for the verse, states that "hasti" must be the most likely choice for this verse because the whole gist of the verse using this word is in accordance with Hâfiz's worldview whereby "Love" is seen as the main purpose of existence and creation. In fact, in this verse Hāfiz refers to a mystical theme that the Eternal Beauty (جمال ازلى: Jamal e Azali), God's beauty, intended to be known and loved. In other words, "Beauty" without "Love" was a commodity without a market. One has to see the manifestation of "Beauty" with "Love" and watch the marvel of Eternal Beauty. Thus, the purpose of existence is "Love." He who does not know "Love" and does not understand it has not understood the secret of creation and has not understood the purpose of being and his life is meaningless (p. 597). The whole verses of this ghazal are concerned with "Love" and as it was discussed in the previous section, the translators have interpreted all the love mentioned in Haafiz's poetry as divine love and attributed it to God. Thus, although the reliable edition for them is Khanlari's and Khanlari has chosen the word "masti" instead of "hasti", by translating "hasti" (existence), they have intentionally deviated from Khanlari's because the gist of the verse including "hasti" is in better accordance with their own worldview; they believe Hâfiz was a mystical person and his poetry is the manifestation of mysticism. Therefore by choosing and replacing hasti with masti they are engaged in manipulating the verse and consequently asserting clearly their own viewpoint. They even go further in manipulation by adding the phrase "both worlds" in the translation which is not mentioned in the original verse. By adding it they assert that in order to enjoy happiness in this world and in the hereafter (both worlds), one needs to show devotion and attention to love.

There are also other infidelities to Khanlari's edition in order to manipulate the interpretation of the verse. For example the following verse:

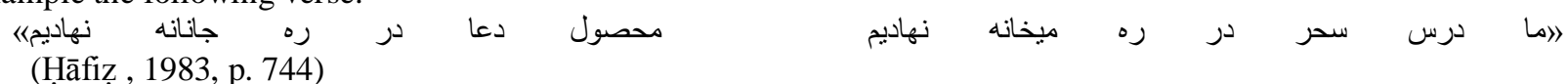

"We have turned the face of our dawn studies

Toward the drunkard's road. The grace earned from our prayers

We have turned over to the road of the Beloved." (Hāfiz et al., 2009, p. 15)

There is a deviation from Khanlari's edition in the first translated part of the verse. According to Khanlari, it should be (ما حاصل خود در ره خمخانه نهاديم) (we have turned the face of our achievement toward the tavern). But the translators

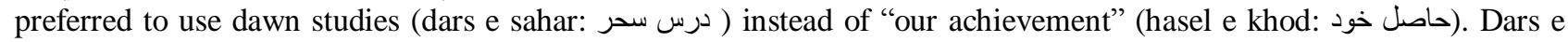
sahar refers to theologians who used to study and practice their religious lessons in the early morning and that is why it is called dawn studies (dars e sahar; a lesson to be studied in the early morning.) Because the subject of the verse is "we" by replacing "achievement" with "dawn studies" it insinuates that Hâfiz himself used to be among the theologians who used to study their religious lessons. In fact, by replacing "dawn studies" Ḥāfiz is characterized due to translators' desire, as a religious and mystical person.

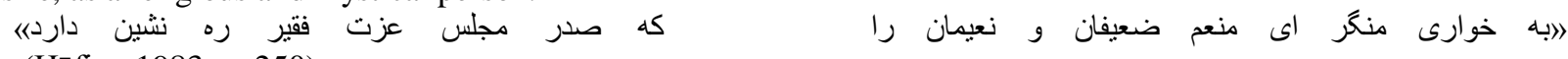

(Hāfiz , 1983, p. 250)

"Do not disparage the weak and the skinny. Remember that,

You men of wealth. We know the one given the chief seat

In the Gathering is the sadhu sleeping in the street." (Hāfiz et al., 2009, p. 55)

This verse is concerned with the contrast between destitution and affluence. It addresses the opulent not to regard the poor with contempt because the chief seat of honor belongs to poor people. In other words, while the destitution and the affluence discussed in the original verse is regarding material possession, the translated verse alludes to mystical and spiritual poverty. By translating the word faqir (فقيز) meaning a poor person to "sadhu" which means a Hindu mendicant ascetic, the translators assigned poverty a spiritual status as if the original verse is concerned with assigning the chief seat of honor to mystics and ascetics. Many think of poverty as an integral part of Sufism and mysticism. As if the necessary condition for being among mystics is poverty and being poor. But in fact the poverty discussed in Sufism and mysticism is not the material poverty it means we are all poor creatures who do not have any possessions compared to God. Because God is the ultimate owner of us and this world. According to mysticism, the real poverty unfolds in comparison to God who is the real owner. That is why mystics not only consider themselves as poor people but also they praise poverty because to them, it means not being proud and arrogant for having any property for we are all nothing against God (Goharin, 2003, p. 172). The translators have made the same mistake about Sufi beliefs and have misinterpreted poverty in Sufi traditions. Choosing such a word shows their misinterpretation of the issue and it alludes to the fact that their mystical worldview affected their translation.

D. Leader-disciple Relationship

$$
\text { آه از اين لطف به انواع عناب آلودهن }
$$$$
\text { |خفت حافظ لغز و نكته به ياران مفروش }
$$

(Hāfiz , 1983, p. 844)

"The Great One replied: "Just cut out selling your friends

These subtle ideas." "Hafez," I said,

"The grace of the teacher is often stained with rebukes." (Hāfiz et al., 2009, p. 6) 
Persian language structure permits the use of a verb without its subject. In Hāfiz's poems while there are lots of verbs without specific subjects, Lewisohn and Bly have specified a subject to each of them in their translation. For example, in the above-mentioned verse, the words "the teacher" and "The Great One" are added to the verse in the course of translation. Adding these words gives the verse a hierarchical atmosphere; as if there is a leader who guides his disciples and gives them advice. Being a disciple and having a leader or master is one of the fundamental basics of mysticism and Sufism. In fact, the master leads, guides and teaches his disciples to step in the right direction. On the other hand, the master is quite respected for the disciples who are obedient to. In this verse, the translators by adding words have introduced Hāäiz as a disciple who is under the guidance of a great teacher (master).

\section{E. Didactic Title}

Like Classical Persian poems, Ḥāfiz’’s poems lack any title. They are recognized using their first verse. Since Hāấz’s poetry encompasses different issues and ideas, it cannot be summarized in a mere title. Before Hāfiz, Persian ghazal was only concerned with the issue of love. Hāfiz was the pioneer who brought a new spirit into ghazal. His ghazals are an amalgamation of several issues such as religion, mysticism, love, social and cultural issues (Korramshãhi, 1994, 115). In other words, a variety of ideas and issues are posed in a single ghazal thus, giving a title to it is not logical. Though Hâfiz’s poetry lacks any title, Bly and Lewisohn, have designated an individual title for each translated poems of Hāfiz. The given titles are taken most of the time, from the verses of the poem itself. In fact, the given titles are in accordance with translators' attitude towards Hāfiz, namely the titles impose translators' interpretation of Haafiz to the readers and also confine the semantic scope of the poem.

As each verse of a ghazal has its own independent idea, due to a lack of consistency giving a single title to it is not possible because some ideas are ignored. A close investigation of the chosen titles reveals the translators' view toward Hâfiz. They considered him a moral preacher who is under the guidance of a master (pir and is in touch with the unseen. Some of the titles are: Some Advice, Do Not Sink Into Sadness, Conversation With the Teacher, What Do We Really Need?, The Angels At the Tavern Door, Gabriel's News, etc. By choosing such titles it can be deduced that the translators have paid attention only to mystical and didactic issues in Haafiz’s's poetry while it is saturated with a variety of different ideas.

Lewisohn and Bly's translation encompasses merely 30 ghazals while the whole Divan has around 500 ghazals and the translation of these 30 poems is actually their own interpretation of Hāfiz. They have introduced him as a moral preacher whose poems maintain didactic instructions. Consequently, if foreigners who are not familiar with the Persian language decide to read Hāfiz’s poetry choosing Lewisohn and Bly's translation they will definitely get to know Haafiz and his poetry filtered through the translators' worldview. In other words, the readers comprehend Lewisohn and Bly's version of Hāâfiz. Hāfiz’s poetry is multi-layered thus it can be interpreted differently. According to Kanaai (2016), ambiguities are major characteristics of Hāfiz's poetry hence, it is possible for every reader to interpret it in accordance with his or her own understanding (p. 449). Since Shafiy (2018) claims, never does art present a single meaning and interpretation (p. 419), therefore, there is no predetermined interpretation for any of Hāfiz's ghazals and his poetry is open to any kind of reading and interpretation. But the translators have only considered the mystical aspect of it and even in some cases as discussed previously, some elements emitting readings in contrast to their interpretation are omitted or it is better to say they have been manipulated to be in accordance with the mystical interpretation of the translators.

Whether Hāfiz was an "aref” and his poetry should be interpreted as secular Persian court poetry or whether it should be interpreted in a mystical and Sufi remains a controversial issue. Yarshater believes whether it is possible to call Hāfiz an "aref" or not depends on the application of this term. If it refers to a person who possesses wisdom and insight about human destiny and life who is a true man of devotion and purity of heart, such an epithet completely suits him. He purports that Hāfiz did not belong to any certain "Order" or the circle of a Sufi mentor. Besides, Sufi's faith in saints who were capable of performing miraculous deeds is far from the clarity of his mind. Thus, in this sense "aref" is a

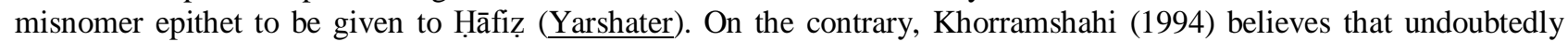
Hâafiz was an "aref" and all those mystical expressions and references to mysticism and Sufism cannot be recognized as aesthetical aspects of his poetry. He continues that Hāfiz himself had a mystical and spiritual experience which is reflected in his poetry (pp.179-180). On the other hand, Shamïsa (2009) believes Asha'rite beliefs have emerged in Haafiz’s poetry but it has unknowingly been interpreted as mysticism. Since eastern mysticism has grown in the context of Ash'arite thoughts, most of the beliefs and thoughts that these days are considered as mysticism are actually a part of Ash'arite axiom and thinking (p.149). In fact, Divan e Hāfiz cannot be considered as mysticism because Sufism and mysticism incorporate a coherent system of theology that holds a worldview but there is no system of theology in Hâfiz’s poetry. It lacks cohesion, namely its components contradict each other. As main mystical texts, there is no contradiction in Masnavi and The Conference of the Birds (Mantiq-ut-Tayr). Although humanism is missed in Sufism and mysticism, Haafiz's poetry is saturated with humanistic perspectives. There are lots of discrepancies in Hāfiz’s poetry because he did not have a stable line of thought toward religion; he thought differently in different moments and it has been reflected in his poems. Thus, he cannot be considered as an "aref' because "aref" has a constant firm faith and nothing can shake it. There is no doubt that Hāfiz was quite familiar with mysticism and Sufi traditions but there is no basis for taking him as an "aref" (Shafiy, 2018, pp. 369-370). Despite different opinions regarding Hāfiz, in fact, it is the translators who have decided to merely reflect Hāfiz’s mystical aspect. Consequently, by means of translating 
Hāfiz’s poetry, they have presented their own worldview and have rendered their own personal version of Hāfiz. In this regard, Carl Ernst (2015) states that "Sufi poetry is not defined by the author so much as by the audience." (p. 209) Therefore, Lewisohn and Bly who are clearly the advocates of mystical interpretation of Hāfiz's poetry, have presented him based on their own desire.

Lefevere and Bassnett (1998) claim translations, especially from third world languages into English are slanted toward English because every foreign and exotic issue is standardized (p. 4). In other words, they believe when third world literature by means of translation enters into western culture it passes through a domestication process in order to prevent any probable violation that might be caused by the entrance of the foreign literature to the nation (Lefevere, 2014 , p. 2). But this claim is not always applicable; for example, in the translation of Hăfiz by Lewisohn and Bly in numerous cases the translation is slanted to Persian, not English though Persian in comparison to English is considered as a third world language. The translators have done their best to reflect eastern mysticism and Sufi traditions in the translation although it has made the translated text seems strange and exotic to the foreign readers. As discussed previously, in the translation they have overindulged to introduce Hāfiz as a mystical poet although the translation of some mystic traditions and issues might hinder the comprehension of the poem because it is too far from the culture and the context of the $21^{\text {th }}$ century western reader. Although Hāfiz can hardly be considered as a mystical poet -his poetry to a great extent is about his social and political life; his poetry is the mirror of his time; he criticizes the king and hypocritical people (Shamïsa, 2009, p. 110) - by highlighting mysticism, they have translated Hāfiz in a way that fits their desired function to fill a gap in the target system.

Lefevere and Bassnett (1998) state that a translation can affect the target system as long as there is a gap in that system which reflects a particular need. In this regard, they continue that the distribution of a foreign text by means of translation relies on three factors: need(s) of the reader, patron and "the relative prestige of the translating and translated language (pp. 60, 44). Since the translators' view contradicts the dominant materialism spirit of the country and era and they are critical about it, ${ }^{1}$ thus they have manipulated the original text to cater to the American society's spiritual needs, namely Ḥāfiz's mystical translation in America seems to act as a safe spiritual asylum. Besides, as Evan-Zohar (1990) purports, as long as a literature is "young" or "peripheral", translation from other literatures answers its need; because it is young and cannot yet establish its own new literature in all fields. Thus, the experience of other literature is quite beneficial for it (p. 48). American literature is not peripheral but it is new compared to Persian literature and it lacks some repertoire related to mysticism thus it needs nourishment from other literature by means of translation and at the same time benefits from it as a weapon against the prevalent materialism of the society and seeks an amendment.

\section{CONCLUSION}

In this paper Hāfiz’s translation by Lewisohn and Bly from a mystical point of view has been investigated. The translators in some cases by manipulating the verses have insisted and highlighted mystical aspects of Hāfiz’s poetry. Although there are a variety of different interpretations for Hāfiz's poetry, they have all been ignored except mysticism. In other words, by means of translation they have rendered their own worldview along with their personal reading of Hāfiz’’s poetry.

Although there are different assumptions regarding the beloved of Hāfiz's poetry, Lewisohn and Bly have interpreted it as God. In fact, they have ascribed any talk of love in Haafiz's poetry to divinity. In some cases, they have applied capitalization in translating the words that refer to the beloved and have given it sacred and divine spirit. Besides, in some other cases the word "God" is explicitly mentioned and has replaced a noun or pronoun in the original poem that refers to the beloved in general. The issue of pedophilia is one of the cultural concepts that is prevalent in Hafez's poetry. This issue is also filtered through their translation and it is omitted as much as possible to prevent demonstrating Hāfiz's beloved as a male. Although they have done their best to fudge and bowdlerize every single sign of praising and longing for the earthly beloved, in some cases where there are conspicuous references to an earthly beloved; they preferred to attribute it to a beautiful woman instead of a young boy. In fact, it is possible to attribute the addressee and the beloved in Hāfiz's poetry to God while it can also be interpreted as an earthly beloved. In other words, it is open to different interpretations but Lewisohn and Bly's version of Hāfiz is confined merely to the mystical aspect and prevents Hāfiz from being labelled a pedophile.

Being highly familiar with eastern mysticism and Sufis traditions, the translators have translated the mystical issues quite intact; they have paid meticulous attention to details to the extent that sometimes it has resulted in introducing Hāfiz as a mystical poet although the translation of some mystic traditions and issues might hinder the comprehension of the poem for foreign readers. The translation of Hāfiz across America by Bly and Lewisohn is a fascinating example of the intricacies of intercultural transfer. Hâfiz was perceived as an emblem of spirituality and challenged the dominant materialism. The Hāfiz who found his way into America was essentially seen as a preacher, whose texts are saturated with moral issues, didactic features, and advice. Regarding the translators' background and their view toward today's

\footnotetext{
1- In the $250^{\text {th }}$ ghazal (Khanlari's edition) in the fifth verse, Hāfiz asks the reader no to sink in sadness even the flood of death sweeps away the foundation of existence but Bly and Lewisohn, have interpreted the flood of death as the flood of materialism: "Even if the flood of materialism Drowns everything, do not sink into

Sadness, because Noah is your captain.” (Lewisohn and Bly 13)
} 
materialism they by means of such a manipulation, might have intended to have an impact on the target system while using translation as an influential force for making social changes and catering to the spiritual needs of the materialistic society.

\section{REFERENCES}

[1] Apter, E. S. (2011). Translation Zone: A New Comparative Literature. Princeton: Princeton University Press.

[2] Bassnett, S. (1998). Comparative literature: a critical introduction. Oxford OX: Blackwell.

[3] Bassnett, S., \& Lefevere André. (1998). Constructing cultures: essays on literary translation. Clevedon: Multilingual Matters.

[4] Ernst, C. W. (2015). Hāafiz and the religion of love in classical Persian poetry. (L. Lewisohn, Ed.). London; New York: I.B. Tauris.

[5] Even-Zohar, I. (1990). Polysystem studies. Durham, NC: Duke University Press.

[6] Goharin, S. S. (2003). An ilustration of Sufi terms. Tehran : Zavar Publication.

[7] Hāfiz . (1983). Divan Qazaliyat Hāfiz . (P. Khanlari, Ed.) Tehran: Nil Publication .

[8] Hāfiz, Bly, R., \& Lewisohn, L. (2009). The angels knocking on the tavern door: thirty poems of Hafez. New York: Harper Perennial.

[9] Hāafiz, Clarke, H. (1891).The Divan-i-Hāfiż. Calcutta: Calcutta Government of India central printing office.

[10] Hamidiyan, S. (2010). Sharhe Shoq (Vol. 5). Tehran: Qatre Publication.

[11] Hassouri, A. (2011). Hāfiz, In other way. Tehran: Cheshmeh Publication .

[12] Javid, H. (1996). Ḥāfiz Javid. Tehran: Farzan Publication .

[13] Kanani, N. (2016). Hafez and his Divan as viewed by the West. Würzburg: Königshausen \& Neumann.

[14] Khaleqi, M. B. (2000). Šãķenabãte Ḥāfiz. Tehran: Zavar Publication .

[15] Khorramshahi, B. (1994). Ḥāfiz. Tehran: Tarhe No.

[16] Lefevere, A. (2014). Translation, a sourcebook. London; New York: Routledge.

[17] Najmabadi, A. (2010). Women with mustaches and men without beards gender and sexual anxieties of Iranian modernity. Berkeley, CA: Univ. of California Press.

[18] Shafiy, M. (2018). In Kimiyaye Hasti. Tehran: Sokhan Publication.

[19] Shamïsa, S. (2002). Pedophilia in the Persian Literature. Tehran: Ferdos.

[20] Shamissa, S. (2007). The Evolution of Ghazal in the Persian Poetry. Tehran: Elm Publication.

[21] Shamïsa, S. (2009). Hāfiż's Notes. Tehran: Elm Publication.

[22] Yarshater, Ehsan. (2002). Hafez.i. An Overview. Encyclopedia Iranica. http://www.iranicaonline.org/articles/hafez-i.

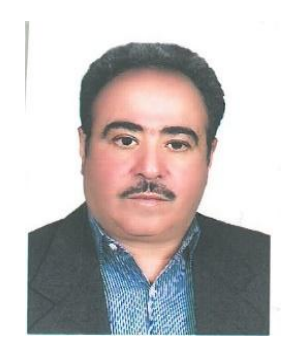

Seyed Mohammad Anoosheh is an associate professor of English Language and Literature in Yazd University, Yazd-Iran. Dr. Seyed Mohammad Anoosheh has published near about 20 papers in different journals. He has also translated 3 books and edited 11 books some of which are being taught in universities of Iran.

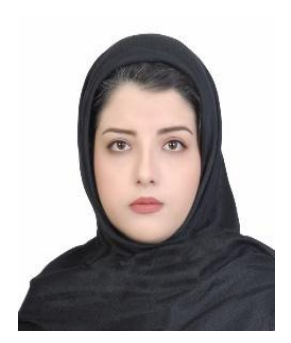

Mahsa Khalili Jahromi was born in Shiraz, Iran in 1994. She received her bachelor's degree in English Language and Literature from Shiraz University, Shiraz-Iran in 2017. She is currently a graduate student of English language and literature in Yazd University, Yazd-Iran. Her major areas of interest and research include translation studies, comparative literature, cultural studies, and world literature. 